\title{
Islamic Religion Value on the Liric Text of Kaili Pop Song Regional Review of Literature in Islamic Education
}

\author{
Yunidar and Ulinsa \\ Universitas Tadulako Palu \\ nuryunidar@yahoo.co.id
}

\begin{abstract}
Lyric of the Kaili Pop song is a literary work that reflects the cultural attitudes of the Kaili society as the owner. The lyrics of the song express feelings or ideas of authors based on the author's life experience. The lyrics of the Kaili's songs that are unique in the theoretical perspective representing the cultural values of Kaili that implicate literature, especially on religious values of Islamic education, (1) prayer (2) repentance, and (3) firmness/resignation. The data of this qualitative research is the text of the lyrics of Kaili pop song. The data source of this research is Kaili songs obtained through audiovisuals in the form of cassettes or CDs. Data were collected through documentation study. The text of the song's lyric was transcribed into the data card sheets and coded according to the focus of the research. The data transcription is analyzed in accordance with the steps of analysis proposed by Ricoeur consisting of (1) semantic understanding stage, (2) reflective understanding stage, and (3) existential understanding stage.
\end{abstract}

\begin{abstract}
Abstrak
Lagu lirik popular Kaili adalah karya sastra yang mencerminkan sikap budaya masyarakat Kaili sebagai pemiliknya. Lirik lagu tersebut mengekspresikan perasaan atau gagasan penulis berdasarkan pengalaman hidup penulis. Lirik lagu Kaili yang unik dalam perspektif teoretis yang mewakili nilai budaya Kailinesse yang menyinggung sastra, terutama mengenai nilai-nilai agama pendidikan Islam seperti: (1) doa (2) pertobatan, dan (3) ketegasan atau pengunduran diri. Data penelitian kualitatif ini adalah teks lirik lagu pop Kaili. Sumber data penelitian ini adalah lagu Kaili yang diperoleh melalui audiovisuals berupa kaset atau CD. Data dikumpulkan melalui studi dokumentasi. Teks lirik lagu itu ditranskripsikan ke dalam lembar data kartu dan dikodekan sesuai dengan fokus penelitian. Transkripsi data dianalisis sesuai dengan langkah-langkah analisis yang diajukan oleh Ricoeur yang terdiri atas tahap pemahaman semantik, reflektif, dan eksistensial.
\end{abstract}

Keywords: Religious Value, Islamic Education, Song Lyrics, Kaili Pop 


\section{A. Introduction}

Literary works have a function to entertain, to give emotional and intellectual enjoyment. Literary works can be viewed as a manifestation of the author's desire to dialogue, offer, and convey something of a view of ideas, morals, and commands on the other hand. Literary works created by an author is inseparable from society and culture. The literature often accentuates the cultural richness of society, ethnicity, or nation deliberately.

Literature may also be created by human that contains beauty. Many authors have defined the literature, but mainly it always relates with beauty. Literature may be defined freely as anything that is printed or it may be expressed in an imaginative work. Thus, literature has many meanings.

Literary works can be viewed as a media of written or verbal communication which is one of the forms of art that convey religious messages or Islamic in form of repentance, petition, and fortitude (resignation). Every literary work, whether traditional literature or local literature or modern literature contains and offers various values that can be guided as a reference in running their lives, for example in a relatively long novel often there is more than one religious value in Islamic nuanced. That is, not to mention based on the considerations or interpretations of the readers who can also vary both in terms of numbers and types, including oral literary works that exist in the ethnic of Kaili. Literary work gives a moral message in form of religious values.

Ethnic of Kaili is one of inhabitants' ethnic of Palu valley area and other areas namely Donggala, Sigi, Parigi Mautong, and Tojo Una-Una and partly spread in Central Sulawesi Province. Ethnic of Kaili has cultural diversity as well as other ethnic groups in the archipelago. Cultural diversity of Kaili ethnic can be seen through the way of life and their livelihood. Ethnic of Kaili lives in mountain plains and do farming, breeding, and hunting, ethnic Kaili who lived in coastal areas do fishing, and those who lived in the land live as entrepreneur, civil servant, building labor, and so on.

The diversity of Kaili's ethnic cannot be separated from the original culture that including oral literature such as lyrics text ofKaili song. The lyrics of Kaili song is an ancestral cultural heritage of Kaili society that is still maintained and preserved by the community of Kaili. As a cultural form of Kaili society, the lyric text of Kaili's pop song has an important 
role and can be used as a grip of life that reflects Kaili's identity and philosophy. Therefore, the lyric text of Kaili's pop song is interesting to be study, especially on Islamic religious values. The message represents the value of Islam as a reflection of Kaili's ethnic identity personality is capable in forming social symbols that can be used as a reference to live flexible. One characteristic that reflects the personality of the Kaili tribe is the lyric text of Kaili's pop song.

The lyric of Kaili's pop song is part of literature that is used as a specific language that is special and different language in general. Literature is often interpreted as a beautiful language, a rhythmic language, which has certain sound patterns such as ritual, rhythm, assonance and alliteration, etc. Literary language is considered different from everyday language because it is not primarily functioning as an author expression tool, not a tool to influence the reader, not to convey something, not to strengthen the bond between people, not to explain abstract language rules, but to attract attention to itself.

The values of Islamic religious that emphasize on how is the relationship of human and God includes: prayer, repentance, and fortitude. These values can be obtained by listeners when they listen to the Kaili pop song. The listener will gain hidden knowledge behind the beauty of the song's lyrics through listening, understanding, and contemplation. Messages and knowledge obtained can be applied in real life every day. Lyrics of Kaili pop songs has an important contribution in the disclosure of the values that contain religious messages based on Islam that invites the song lovers to understand and apply the religious messages contained in lyrics. Furthermore, the values of religion greatly affects the behavior and actions of human beings whether done by individuals or groups.

Religious values in literary works especially on the lyrics of Kaili's pop song are very necessary because it influenced the inner awareness of listener to bea good human being. Religious values of awareness of understanding and appreciation of Islamic-based especially in the current globalization era needs to be instilled to the listeners; therefore the lyrics of Kaili's pop song can be used as the benchmarks of faith builders. 
Literature is the result of human creation that has beauty. The beauty that we can see in a series of words composed by many authors ${ }^{1}$. They suggest three definitions of literature. Firstly, literature is everything written or printed. In that sense, everything written, whether medical science, social science, or whatever is written is literary. Secondly, literature is limited only to "great books", books that are considered prominent because of their form and literary expression. In this case the criteria used are aesthetic, or aesthetic value combined to scientific value. Lastly, literature is applied to the literary art that is seen as imaginative works, which have beautiful and polite writing.

Literary works are works of art that desire creativity. The concept of literature is imaginative, literature is the result of experience and the result of that experience becomes a new discovery arranged into a system with the power of imagination to create a new world that had never been existed before.

The benefits of literary works need to be restored through considering some matters relating to literature such as; 1) the rise of culture studies; 2) among literary works, works of art occupy dominant position, with the utilization of language aspect as communication system; 3) increasingly away from society towards aesthetic elements, considered as one indicator of the increasing number of violence; 4) the dissemination of literary works, through its beauty aspects does not require significant energy and cost, concrete efforts that can be made in situations of economic crisis; and 5) literary works have existed since ancient times as a tradition, so it only requires the process of habituation as revitalization. Messages and contents can have forms, both oral and $w_{\text {written }}^{2}$. This qualitative research uses hermeneutic approach. The focus of the study is the lyric of Kaili pop song which represent religion based on Islam.

The data used in this study are the lyrics from two Kaili's songs. The first song is Ina Toveaku (Mother of whom I love), whilst the second song is Nipokiomo Ntupu (Called by God). The third is Matobamo song. The fourth song is Tupu Mbabalasina (God pay it back). The data were gathered from audio and audio-visual recordings.

\footnotetext{
${ }^{1}$ Wellek, Ren and Warren, Austin, Teori Kesusastraan. Translated by Melani Budianta, (Jakarta: Gramedia, 1995), 21.

${ }^{2}$ Ratna, Nyoman Kutha, Sastra dan Cultural Studies: Representasi Fiksi dan Fakta, (Yogyakarta: Pustaka Pelajar, 2010), 521.
} 
Data were collected through documentation. Documents of audio and audio-visual recordings are transcribed to obtain written documentation. Transcribed documents are copied back in form of data sheets. After a number of song lyric texts have been collected and manifested in the data sheets, the researcher checks the relevance according to the research focus.

The first data analyzed in this research is text lyric of Kaili op song. Data analysis in this study follow the steps proposed by Ricoeur which includes anything that was expecting to see being discussed in any findings and discussion session., however, it was not there, and if it does it is not clearly stated. ${ }^{3}$ At the stage of semantic understanding, reading and understanding are made. Activities undertaken at this stage include data identification and data classification. In this reflective stage, an explanation and deepening of the findings are made. Furthermore, at the stage of existence the author carried out the meaning extension of the truth of the findings.

\section{B. The Nature of Values}

The term values have various definitions. The matter of beauty is the matter of art. ${ }^{4}$ Art is all that creates a plan of beauty or novelty and all that is created to produce plan. The plan spawned fun and aimed to be fun. Furthermore, beauty though is not identical, related intimately with kindness. ${ }^{5}$ In this case, aesthetics are closely related to ethics; good is beautiful, and beautiful is good.

Values are the ones that are understood about what is more important or less important, what is better or less good, and what is more correct or less true. ${ }^{6}$ Meanwhile, Mattulada (1995:154) states that values are qualities or special things, useful and desirable or at least wanted by humans. ${ }^{7}$ Value can also be defined as something that satisfies the needs or desires of man and as the quality of a response.

\footnotetext{
${ }^{3}$ Paul Ricoeur, Filsafat Wacana: Membedah Makna dalam Anatomi Bahas, Translated by Musnur Hery, (Yogyakarta: IRCISOD, 2002), 121.

4 Clifford Geertz, Tafsir Kebudayaan, Terjemahan Fransisco Budi Hardiman, (Yogyakarta: Kanisius, 1993), 107.

${ }^{5}$ Ibid.

${ }^{6}$ James Danandjaja, Foklor Indonesia, (Jakarta: Pustaka Utama Grafiti, 1991), 73.

${ }^{7}$ Mattulada, A, Latoa, Satu Lukisan Antropologi Politik Orang Bugis, (Ujung Pandang: Hasanuddin University Press, 1995), 154.
} 
It can be concluded that the value is a character owned by an object or quality on a particular object. Nature or quality is seen through the manifestation that will be actualized if there is a relationship between the object and the subject (human). In addition to the above values, there are also four different meanings of value. First, the value is useful. Second, it is good, big, or beautiful. Third, contains value means that there are character that can lead to the attitude of agree or the attitude to want to have it. Fourth, giving value means deciding that something has certain ability (certainty). It indicates that the understanding of many experts' about value is different according to the respective viewpoints.

Value refers to a person's attitude towards something good. ${ }^{8}$ Values can be interconnected to form a system of one another, coherent, and affect the human life. Thus, it can be concluded that value is the character or things that are important and useful to humans. Value cannot be separated from human life. Values are always being pursued, defended, aspired, and coveted so that their presence is always become a motivation to every human activity. Man acts, behind every action and behavior there is always a motive humans do because they wants to achieve something.

\section{Definition of Religion}

The word religion comes from Latin language that is relegere which means collecting and reading or binding in other opinion. Religious do have the nature of binding for humans with their God. Nurgiyantoro, (2002:216) suggests that there is a difference between religion to religiosity. ${ }^{9}$ Religion refers to the institutional devotions to God and official laws, while religiosity is transcended deeper and broader than visible, formal, and official religion. Thus it can be concluded that religion is a feeling that is more directed to its existence as a human being because of its personalities and its scope that is more broadly than religion that limited only to teachings and connections.

The religious value or divinity in the literature is a matter of literary existence itself. ${ }^{10}$ Literature grew up through religious nature.

\footnotetext{
${ }^{8}$ A.A Djelantik, Estetika sebuah Pengantar: Masyarakat Seni Pertunjukkan Indonesia. (Bandung: MSPI, 1999), 55.

${ }^{9}$ Burhan Nurgiyantoro, Teori Pengkajian Fiksi. (Yogyakarta: Gajah Mada University Press, 2002), 216.

${ }^{10}$ Ibid, 327.
} 
The divinity value upholds human qualities of a deep conscience, the dignity and the personal freedom that humans possess. A message contains value of divinity in poetry is a communication between the author and his Lord to represent others in expressing his feelings and able to bring humans to be more cautious, more contemplating to the power of God and respecting the whole world. ${ }^{11}$

\section{Concept of Text}

Text can be defined as a language expression composed of contents, syntax, pragmatics which are an inseparable unit of unity. ${ }^{12}$ There are three things that must exist in a text, namely content, syntax, and pragmatics.

First, the content is related to the idea of a text. The text must reveal the ideas or images that exist in life. Such ideas or images are expressed in drama and prose or word sequences, usually in poetry. Author can explicitly and implicitly pour ideas to show the content as the message conveyed in the text. The content in the text is closely related to semantics. Semantics is one of the studies in language related to meaning. Content in the text is like the meanings conveyed by the author. This expression of meaning can be done openly, straightly, clearly, or hidden through symbols.

Second, syntax in the grammar is defined as a sentence. Syntactically a text must show a link. The link will be seen if the grammatical elements functioning as a pointer (conjunction) are used consistently. The use of pronouns as conjunctions can be found in poetry, for example in the kiltlike of $m u$ or $k u$ may substitute or refer to the name of the person spoken in a poetic text. Syntax is so important in a text as well as the consistency of conjunction so it is not confuse sentences that build stories or vocabulary, paraphrase, or sentences that build poetry.

Third, pragmatics deals with situations or circumstances when language is used. Pragmatic is related to how language is used in a particular social context; text is a unity of expression in the language used by participants in speech. ${ }^{13}$ Pragmatic is a science related to the

\footnotetext{
${ }^{11}$ Herman J Waluyo., Memahami Puisi, (Bandung: Angkasa, 1995), 17.

12 Jan Van Luxemburg, Tentang Sastra, Translated by Akhadiati Ikram (Jakarta: Intermasa, 1991), 51.

13 Aminuddin, Pendekatan Tekstual dalam Analisis Bahasa Kias dalam Puisi Sekitar Masalah Sastra, (Malang: YA3, 1990), 17.
} 
context behind the speech. It is expressed by Luxemburg that is closely related to the completeness in understanding a text. The meaning of unity leads to the unity of a text.

\section{E. Lyric of Song}

A poet does not really concern to the language used in writing song. The use of written language is loose as the language used in casual situations, but cannot be separated from the creative process, word selection and language. The same thing is expressed by Waluyo that the lyrics of a song are examples of common poetry. ${ }^{14}$ The characteristic of general poetry is that the language should be easy to understand, because the listener must quickly understand the content when the song is being heard.

A songwriter can be equated to a poet. Poetry is a form of literature that expresses the poet's thoughts and feelings imaginatively and is compiled by concentrating all the power of language, namely the physical structure and inner structure. ${ }^{15}$ The physical structure of the language is the language used, while the inner structure is the meaning and message of the thoughts and feelings expressed by the poet. Both elements are functionally interconnected.

Another writer expresses that the text of the song has meaning in the form of words or sentences that can be used to create a certain atmosphere and imagination to the audience so that it can also create diverse meanings. ${ }^{16}$ In its function as an oral communication medium, the song is often used as a means to invite sympathy about the reality that is happening as well as on imaginative stories. Ethnic of Kaili has a language as an ancestral heritage that is still preserved and used in their lives. The language that is alive and used in everyday conversations is about twenty languages. ${ }^{17}$

The poet has a specific purpose when composing the lines and stanzas in such a way, as well as the use of words, symbols, figures, and so on. The lyrics of the song that the poet shows have meaning, because the words used are a form of emotive expressions embodied in sounds

\footnotetext{
${ }^{14}$ Herman J Waluyo,., Memahami Puisi, (Bandung: Angkasa, 1995), 2.

${ }^{15}$ Ibid, 25.

${ }^{16}$ Widarmanto, Tjahjono, Masa Depan Sastra (Mosaik Telaah dan Pengajaran Sastra, (Lamongan: Pustaka Ilalang, 2013), 15.

17 Abdillah Rahim, Tata Bahasa Kaili, (Jakarta: Pusat Pembinaan dan Pengembangan Bahasa Depdikbud, 1998), 2.
} 
and words. Therefore, the song lyrics produced must use a language that is capable of giving aesthetic pleasure to the listener. Aesthetic pleasure in the language is the feeling of pleasure in the listener generated by the use of beautiful, delicate, melodic language that reflects artistic taste of the author.

The beauty of language is made through the selection of words that show the right taste, sound, rhythm, or idiom. This makes the use of language in the lyrics of the song has special features that distinguish the use of other languages. A songwriter in writing lyrical songs emphasizes linguistic factors to realize his work, among others: the choice of words and style of language. ${ }^{18}$

\section{Song of Kaili (Kailinese Song)}

Kaili's song is an expression of the author's feelings as Kaili speakers in pouring ideas by using Kaili language as his tool. Kaili's song contains a number of events that occur in daily life of the Kailinese. The event was a religious, social, ethical and aesthetic activity that depicted Kaili's ethnic culture. The lyrics of the Kaili song is the result of the imagination of the author or songwriter of Kaili's song based on what he feels, sees, and experiences. In addition, the lyrics of Kaili's song have a distinctive physical structure, style, and message and may be different from other lyrical texts. ${ }^{19}$

The text of Kaili's song lyrics is the cultural heritage of the Kaili community. The lyrics text of Kaili song has a number of aesthetic values that are quite varied. It can be seen through the representation of aesthetic values on the physical structure, language style, and text messages that describe the unique beauty value of it and also as a picture of Kailinese (society/community) life. Kaili's song is written by the author with a language game that includes vocal games, word choices, language styles, and meanings. The game of language or deviation is done by the author solely to effects the attraction or uniqueness of the song that was created. In addition, the author in writing songs based on the results of imagination or in the form of ideas obtained through the events seen or

\footnotetext{
${ }^{18}$ The Liang Gie, Filsafat Keindahan, (Yogyakarta: Pusat Belajar Ilmu Berguna, 2004), 45.

${ }^{19}$ Budi Kritianto, Suku Bangsa Kaili dari Sejarah Hingga Budaya, (Manado: BKSNT). 17.
} 
occurs around the life of the community or even experienced by the author himself.

\section{F. Findings and Discussion}

Each literary text, both oral and written, contains a message to convey to the reader or hearer. The message in question is the divinity message which includes (1) prayer (2) repentance, (3) gratuitousness and (4) piety. The description of the results of this research presents the exposure of the results in accordance to the focus of the four divinity messages in the text of Kaili pop lyrics. The description s can be seen below.

\section{G. Prayer Message}

The divinity value that contains a request message that is represented in the text of Kailipop song through Ina Toveaku (Mother of whom I love) can be seen in the following song text.

Data 1

Kailinese Language

Oh Tupu tarima tinaku

Singgani ante amalana

Potove ripekapuimu

Ala masana tuvuna hamai

The translation

Oh God accept my mother

along with her charity

so she will live happily there in the paradise

Love her in your arms

The description of illustration above is form of semantic understanding analysis of the divinity value that contains the prayer message. Then, through the text translation of the song's lyrics to the quotation, there is a divinity value that describes the relationship of the Kailinese with their God in asking prayer for the salvation of the mother who has returned to Him as a reflective understanding.

The description of the understanding of existence or extension of meaning shows that in the text of the song's lyrics, there is a message that represents the divinity value that appears in the quotation/Oh Tupu tarima tinaku/, /Singgani ante amalana/, /Potove ripekapuimu/, dan /Ala masana tuvuna hamai/ artinya /Oh God accept my mother /, /along with her charity/, /so she will live happily there in the paradise /, and/Love her 
in your arms/.Through the quotation, we get a message showing the value of the divinity that represents His servant's prayer to God" Kita kana mbatora reso nutinata ante mbapotovena ante merapi doa nte Tupu Taala maupa tinata nokaulumo nte Tupu" means "We always remember the work of a mother and always love her by praying to God even though our mother has returned to God".

The message is a uniqueness that reflects the divine personality ethnic Kaili through communicating to his Lord to ask for pleasure on what he asks for. The communication ties pictured in the text represent a person to pray to God.

The text of the song lyrics above contains religious values that represent messages that describe the relationship between human beings with their creator. The message of the petition can be demonstrated through the occurrence of communication between man and their God used to invoke the salvation prayer for a mother who has returned to Him (God). The message reflects personality and tradition of Kailinese in communicating to their God to ask for their wishes. The communication ties depicted in the text of the song's lyrics represent a person to ask God as a slave, in this case a child's plea to God for his mother to be accepted for his good deeds to have a place in heaven.

The results of the analysis of prayer shows the value of the divinity that can be seen in the text of the song lyrics called Nipokiomo Ntupu (Called by God) as seen below:

Data 2

Kailinese Language

Oh .... Tupu

Paka mbaso raraku

Natuvu ante ondo rara

Kuperapi nte Tupu

Ala rapodotakana

Damo Ri ahera Ngena

Rapojodota

The Translation

Oh .... God

Breathe my heart

Live with sorrow

I ask to God

In order he desires

Live in the heaven later 
We are mate

The description of illustration above showed the semantic understanding analysis of the divinity message contains the request message in the quotation. Then, through the text translation of the song's lyrics on the quotation, a message of divinity value represents the relationship of Kailinese to their God in asking for a raising his heart that lives in sorrow and pray to God that the unrealized mate in the world can be realized in the heaven as a reflective understanding .

The description of understanding of extension of meaning indicates that in the text of the song's lyrics, there is a message that represents the divine value containing the message of the petition appear on the quotation

The description of the understanding of existence or extension of meaning shows that in the text of the song's lyrics, there is a message that represents the divinity value that appears in the quotation/Oh ... Tupu/, /Paka mbaso raraku/, /Natuvu ante ondo rara/, /Kuperapi nte Tupu/, /Ala rapodotakana/, /Damo Ri ahera Ngena/, dan /Rapojodota/means/Oh .... God/, /Breathe my heart/, / Live with sorrow /, / I ask to God /, /In order he desires/, / Live in the heaven later /, dan / We are mate/.

A message denoting the divinity value through the quotation is "Kita maikhlasi ante mosabara mantarima were dako nte Tupu apa Tири natau пиара апи nabelo kakita ante nitantukanamo isema jodo kakita" means "We must sincerely and patiently accept the fate of God because God knows what is best for his servant and has determined who is the soul mate of each servant." The message is a uniqueness that reflects the personality of divinity values possessed by the ethnic Kaili who is consider that ancestral heritage need to be upheld and used as a grip of life in everyday life.

\section{H. Repentance Message}

Analysis result of the use of message that shows divinity value contains repentance message can be seen through lyric text of Matobamo song:

Data 3

Kailinese Language

Matoba-matoba mo

Nemo botoro

Maje-majea mo

Ne mangali nomoro 
Inda nipolea

Mbara naopu nipobalu

Katuvua ledo nasiyayu

Translation

Please be repentance

Do not gamble

Please be deterrent

Do not buy number (white coupon)

Debt bears

Treasures sold out

Life is a mess

Description above illustrates form of semantic understanding analysis to the message of the divinity value which contains a message of repentance. A message of divinity value through the songs' translation above represents the relationship of the Kaili's man to his God in expressing repentance in order not to gamble as a reflective understanding.

The description of the understanding of existence or extension of meaning shows that in the text of the song's lyrics, there is a message that represents the divinity value that contains repentance value "Matobamatoba mo,nemo botoro,maje-majea mo, ne mangali nomoro, inda nipolea, mbara naopu nipobalu, katuvua ledo nasiyayu". means "Please be repentance, Do not gamble, Please be deterrent, Do not buy number (white coupon), Debt bears, Treasures sold out, Life is a mess". The Messageis a uniqueness that reflects the divine personality possessed by the ethnic Kailinese who is consider that ancestral heritage need to be upheld and used as guidance of life in everyday life, where the act of gambling is prohibited by God because it can damage human life.

\section{Firmness (Resignation Message)}

Analysis result of the use of message that shows divinity value contains repentance message can be seen through lyric text of Tupu Mbabalasina (God pay it back).

Data 4

Kailinese Language

Abala nuapa nikavaku

Sampe-sampe yaku nisangka nangganga 


\section{Ea mataku gero nularaku}

Translation

Damo ranga Tupu mombalasina

What disaster can I get

So, I was accused of stealing

I am ashamed my heart is broken

Only God can pay it back

Description above illustrates form of semantic understanding analysis to the message of the divinity value which contains a message of firmness/resignation. A message of firmness/resignation message through the songs' translation above represents the relationship of the Kaili's man to his God in asking for a prayer the slanders will pay the price through God.

The description of the understanding of existence or extension of meaning shows that in the text of the song's lyrics, there is a message that represents the divinity value that contains in firmness/resignation message. /Abala nuapa nikavaku/, /Sampe-sampe yaku nisangka nangganga/, /Ea mataku gero nularaku/, and /Damo ranga Tupu mombalasina/ means/What disaster can I get/, /So, I was accused of stealing, /I am ashamed my heart is broken/, and/Only God can pay it back/.

Message obtained from the quotation revealed divinity value of: "Ane tona makasara ante mbafitna kita nemo kita mbaboli tida nulara tapi posabaramo ante pasrakamo ka Tupu mombalasina apa kita manusia nosimbayu ri mata Ntupu" means "If people are rude and slanderous we should not put a sense of resentment but be patient and leave it to God to reciprocate because man is equal in front of God.". The message is a uniqueness that reflects the personality of divinity values possessed by the ethnic of Kaili who consider that ancestral heritage need to be upheld and cultivated in everyday life.

\section{J. Conclusion}

Form of Islamic divinity is represented in the text of the lyrics of Kaili's pop song, including 1) the message of prayer, 2) the message of repentance, and 3) the message of firmness/resignation. Moral messages in the form of religious values conveyed through the song illustrates that the community of Kaili tribe strongly put forward the relationship between humans and their God that tells on every poem on the song he wrote. 
This manifestation is a reflection of the value of social life, psychological turmoil, and all aspects caused by the power of social interaction, either directly or indirectly, in a certain time and atmosphere.

\section{Bibliography}

Aminuddin, 1990, Pendekatan Tekstual dalam Analisis Bahasa Kias dalam Puisi Sekitar Masalah Sastra, Malang: YA3.

Danandjaja, James., 1991, Foklor Indonesia, Jakarta: Pustaka utama Grafiti.

Djelantik, A.A. 1999. Estetika sebuah Pengantar: Masyarakat Seni Pertunjukkan Indonesia. Bandung: MSPI.

Geertz, Clifford, 1993, Tafsir Kebudayaan, Terjemahan Fransisco Budi Hardiman, Yogyakarta: Kanisius.

Gie, The Liang, 2004, Filsafat Keindahan, Yogyakarta: Pusat Belajar Ilmu Berguna (PUBIB).

Kritianto, Budi, 2002, Suku Bangsa Kaili dari Sejarah Hingga Budaya, Manado: BKSNT

Luxemburg, Jan Van, 1991, Tentang Sastra, Terjemahan Akhadiati Ikram, 1991. Jakarta: Intermasa.

Mattulada, A. 1995, Latoa, Satu Lukisan Antropologi Politik Orang Bugis, Ujung Pandang: Hasanuddin University Press.

Nurgiyantoro, Burhan, 2002, Teori Pengkajian Fiksi. Yogyakarta: Gajah Mada University Press.

Rahim, Abdillah, 1998, Tata Bahasa Kaili, Jakarta: Pusat Pembinaan dan Pengembangan Bahasa Depdikbud.

Ratna, Nyoman Kutha, 2010, Sastra dan Cultural Studies: Representasi Fiksi dan Fakta, Yogyakarta: Pustaka Pelajar.

Ricoeur, Paul, 2002, Filsafat Wacana; Membedah Makna dalam Anatomi Bahas, Terjemahan Oleh Musnur Hery, Yogyakarta: IRCISOD.

Waluyo, Heman J., 1995, Memahami Puisi, Bandung: Angkasa.

Wellek, Ren and Warren, Austin, 1995, Teori Kesusastraan. Terjemahan Melani Budianta, Jakarta: Gramedia.

Widarmanto, Tjahjono, 2013, Masa Depan Sastra (Mosaik Telaah dan Pengajaran Sastra, Lamongan: Pustaka Ilalang 